\title{
Commentary
}

\section{Proposal of a short form self-reported financial wellbeing scale for inclusion in the 2026 Census}

Ferdi Botha* The University of Melbourne

John P. de New The University of Melbourne

* Corresponding author. Email: ferdi.botha@unimelb.edu.au. Address: Melbourne Institute: Applied Economic \& Social Research, Faculty of Business and Economics, 111 Barry Street, Carlton, Victoria 3010, Australia.

Paper received 12 February 2021; accepted 19 April 2021; published 31 May 2021

\section{Introduction}

The Australian Bureau of Statistics (ABS) regularly invites suggestions for new content or themes for inclusion in the next national Census of Population and Housing. This provides a unique opportunity to include current and relevant questions, as well as to keep up to date with changes in the needs of society. Following extensive consultation and reviewing more than 400 submissions (ABS 2018), for the 2021 Census the ABS decided to include a new question on long-term health conditions and a new question on service in the Australian Defence Force, removed a question on internet usage, and made a few minor text adjustments to existing questions (ABS 2020).

With the next Census due in 2026, there is again a unique opportunity for new content to be included, with invitations from the ABS for submissions of additional material. In this paper, we argue for the inclusion of a five-item question battery that together constitutes a validated and straightforward measure of subjective, or perceived, financial wellbeing.

\section{Proposed Census questions on financial wellbeing}

Based on a review of previous research (CFPB 2017; Muir et al. 2017; Netemeyer et al. 2018), Comerton-Forde et al. (2018 p. 6) defined financial wellbeing as "the extent to which people both perceive and have (i) financial outcomes in which they meet their financial obligations, (ii) financial freedom to make choices that allow them to enjoy life, (iii) control of their finances, and (iv) financial security - now, in the future, and under possible adverse circumstances." This definition therefore captures functional, situational, and temporal dimensions.

Consistent with this definition and in collaboration with Commonwealth Bank of Australia (CBA), Comerton-Forde et al. (2018) developed a 10-item financial wellbeing scale, termed the CBA-MI Reported Financial Wellbeing Scale, for Australian banking customers based on rigorous analyses of 
potential existing items ${ }^{1}$. Using these ten items as a reference point, Botha et al. (2020) subsequently created an abbreviated 5-item financial wellbeing scale, termed the CBA-MI Reported Financial Wellbeing Scale 5 (or R-5 in this paper). We propose this set of five questions, listed in Table 1, for inclusion in the 2026 Census. Each item is measured on a five-point Likert scale; together the five items make up the R-5 scale.

The R-5 was designed to align with Comerton-Forde et al.'s (2018) definition and covers immediate or daily financial outcomes (items 1, 3, and 4), buffering financial wellbeing during unexpected events (item 2), and reaching long-term financial goals (item 5). The R-5 was rigorously tested and validated via a range of methods, including factor analyses and Item Response Theory (IRT) ${ }^{2}$. The correlation between the R-5 and Comerton-Forde et al.'s (2018) original 10-item scale is $95.2 \%$, and the abbreviated R-5 scale also performs very similarly to the 10 -item scale in terms of its overall distribution and relationship with a range of observed variables (Botha et al. 2020). The correlation between the summation R-5 scale and the predicted latent R- 5 scale from IRT analyses was $99.2 \%$. The R-5 scale's reliability is excellent, moreover, with the Cronbach alpha coefficient of internal consistency (reliability) being 0.86 (Botha et al. 2020) and 0.91 (Botha et al. 2021) reported in previous work.

Importantly, in addition to having been rigorously tested and validated (Botha et al. 2020), the R-5 has also been applied more broadly using Australian survey data that studies the impact of the COVID-19 pandemic on Australians' financial wellbeing (Botha et al. 2021). Publication of the latter study in the peer-reviewed academic journal Journal of Population Economics further attests to the academic community's increasing acceptance of the R-5 measure as a valid and reliable measure of self-reported financial wellbeing. The R-5 items have also been included in the 2020 wave of the Household, Income and Labour Dynamics in Australia (HILDA) Survey to be released in the second half of 2021. One advantage here is that the R-5 measure can be combined with the rich questions of the 20-year running household panel. Unfortunately, the sample size of the HILDA panel will not allow for certain important types of analyses such as detailed regional analyses, or occupation/industry-specific analyses; that can only be done with the census.

The R-5 items are easy to understand, do not impose a heavy cognitive load on respondents, and can be answered quickly. The R-5 scale is also very simple for researchers to construct: Summing the responses to each of the items and multiplying the sum by five produces the $R-5$ scale that ranges

\footnotetext{
${ }^{1}$ Comerton-Forde et al. (2018) also developed the CBA-MI Observed Financial Wellbeing Scale (version 1) and Haisken-DeNew et al. (2019) developed an adapted version termed the CBA-MI Observed Financial Wellbeing Scale (version 2), which consist of five items derived from bank customers' actual bank records. The Observed Scales were also subsequently used in conjunction with the 10-item Reported Scale to understand better Australians' financial wellbeing (Haisken-DeNew et al. 2018; Comerton-Forde et al. 2020). In Botha et al. (2020), the R-5 scale was compared to the Observed Scale (version 2), with a correlation of $42.9 \%$. This suggests that higher self-reported financial wellbeing tends to be associated with higher observed financial wellbeing, based on actual bank records. However, self-reported and observed financial wellbeing are themselves also distinct concepts and distinct components of overall financial wellbeing.

${ }^{2}$ For more information about the validation procedures and statistical properties of the R-5 scale, see Botha et al. (2020).
} 
Table 1: Proposed Census questions on perceived financial wellbeing items

\begin{tabular}{|c|c|c|}
\hline Item & Question & Responses \\
\hline 1 & I can enjoy life because of the way I'm managing my finances. & $\begin{array}{l}0-\text { Not at all } \\
1-\text { Very little } \\
2-\text { Somewhat } \\
3-\text { Very well } \\
4-\text { Completely }\end{array}$ \\
\hline 2 & I could handle a major unexpected expense. & $\begin{array}{l}0-\text { Not at all } \\
1-\text { Very little } \\
2-\text { Somewhat } \\
3-\text { Very well } \\
4-\text { Completely }\end{array}$ \\
\hline 3 & I feel on top of my day to day finances. & $\begin{array}{l}0 \text { - Disagree strongly } \\
1 \text { - Disagree } \\
2 \text { - Neither agree nor disagree } \\
3 \text { - Agree } \\
4 \text { - Strongly agree }\end{array}$ \\
\hline 4 & I am comfortable with my current levels of spending. & $\begin{array}{l}0 \text { - Disagree strongly } \\
1 \text { - Disagree } \\
2 \text { - Neither agree nor disagree } \\
3 \text { - Agree } \\
4 \text { - Strongly agree }\end{array}$ \\
\hline 5 & $\begin{array}{l}\text { I am on track to have enough money to provide for my financial } \\
\text { needs in the future. }\end{array}$ & $\begin{array}{l}0 \text { - Disagree strongly } \\
1 \text { - Disagree } \\
2 \text { - Neither agree nor disagree } \\
3 \text { - Agree } \\
4 \text { - Strongly agree }\end{array}$ \\
\hline
\end{tabular}

Source: Botha et al. (2020)

Note: All five items are summed together and multiplied by the factor 5 to obtain the overall R- 5 score ranging from 0 to 100.

from 0 (low financial wellbeing) to 100 (high financial wellbeing) ${ }^{3}$. As an example, for each item in Table 1 person A may select responses consistent with the values of 3, 1, 2, 3, and 2. Person A's financial wellbeing score would thus be $(3+1+2+3+2) \times 5=55$. Person $B^{\prime}$ s responses may be consistent with the values of $4,3,4,2$, and 3 , which will produce a financial wellbeing score of $(4+3+4+2+3) \times 5=80$. Clearly, person $B$ has higher perceived financial wellbeing relative to person $A$. As also alluded to in the next section, however, such a result would not necessarily imply that person B has a higher income than person A. It is entirely possible, and is often the case, that people with higher (lower) levels of income may have relatively lower (higher) financial wellbeing. A simple focus on income alone can therefore provide a misleading picture of people's financial wellbeing position, as "financial wellbeing gives us a holistic view of the true pressures felt by all individuals across the income and wealth distribution..." (Botha et al. 2021 p. 656). With financial

\footnotetext{
${ }^{3}$ Botha et al. $(2020,2021)$ found that the simple summation of the R-5 performed equally well compared to a latent factor score predicted from IRT analyses. For ease of computation and interpretation, therefore, the summation R-5 score is an acceptable and simple measure of self-reported financial wellbeing.
} 
wellbeing, we capture how people are able to respond to shocks, the extent to which they are financially constrained, and people's ability to plan for future financial needs.

Australian households have one of the highest private household debt rates in the world with a household debt-to-income ratio of around 200 per cent (Kearns et al. 2020). Much of this is driven by real-estate purchases and can leave even relatively well-off households "cash-strapped", living month-to-month. On paper, a household's income may be substantial, yet inflexible monthly expenses of high mortgage payments leave the household with limited options in the face of unexpected expenses or economic uncertainties. Given the central role of real-estate prices in the Australian economy, this effect is likely only to increase over time.

\section{Advantages and expected returns}

Inclusion of the R-5 scale in the 2026 Census would enable stakeholders to obtain an overarching view of perceived financial wellbeing across the entire country. For government, the financial wellbeing questions would provide an indication of how Australians are doing financially in a holistic sense. For researchers, availability of the financial wellbeing questions would allow for a wide range of analyses into what personal and household factors may be contributing to financial wellbeing, or how financial wellbeing may affect other spheres of Australians' lives. This financial wellbeing scale allows one to addresses the entire distribution and does not focus simply on the left tail of the distribution as a "financial stress" measure is likely to do. Rather, financial wellbeing can also address equally and quite readily improvements in the right tail of the distribution (those with higher levels of financial wellbeing). The scale is specifically designed to pick up movements in all parts of the distribution, well beyond a focus on only averages.

Anyone aged 15 and older can answer the financial wellbeing battery of questions. For both the Australian HILDA panel and the Australian Census, it is the same target respondent population. The financial wellbeing scale battery also easily lends itself to individuals in a household context. Individuals in the same household can easily have different answers, especially if there are young adults still living at home along with their parents. Also given the plethora of non-standard cohabitation relationships, the finances of two cohabiting adults may be completely separate, despite living at the same address. Therefore, the R-5 questions in the Census would also allow for analyses of within-household differences in perceived financial wellbeing.

Although previous census rounds have consistently included information on factors such as total personal income and total household income, questions on individuals' financial wellbeing have never been asked in the Australian census. As far as could be determined, no other national census in the world asks citizens about their financial wellbeing using a robust and validated financial wellbeing instrument. The 2026 Australian Census would thus be an ideal opportunity to collect financial wellbeing information from Australian citizens, and availability of financial wellbeing measures in a national census would be a world first.

Given the large number of observations in a census, detailed regional analyses will also be possible, to examine financial wellbeing inequalities even within fine geographical areas. Moreover, though income provides important information on people's economic circumstances, income is explicitly not synonymous with financial wellbeing (e.g., Bonke and Browning 2009; Brown and Gray 2016; 
Haisken-DeNew et al. 2018), and the correlation between income and financial wellbeing (using the $\mathrm{R}-5$ scale) is in the range of 0.32 to 0.38 (Botha et al. 2020). According to Botha et al. (2021 pp. 661 662):

...financial wellbeing is preferable to income [alone] in that it is multi-faceted, capturing several dimensions of individual financial enjoyment such as uncertainty and future-oriented consumption that a simple income measure cannot. It also uses several items across a range of outcomes, averaging out measurement error [...] [Financial wellbeing] can be constructed from only a few [inobtrusive] questions that most survey respondents will gladly answer, [in comparison to income item survey nonresponse]".

Addition of the R-5 items in the census would thus provide a much broader insight into Australians' financial lives, including the day-to-day enjoyment of their income, provision of adequate funds for the future, and building resilience to adverse economic shocks, such as sudden international trade disputes, bushfires, pandemics, floods, and other natural disasters. The types of analyses possible include, for example: simple means or averages, tracking of financial wellbeing values at different quantiles of the distribution, calculating measures of inequality based on these quantile values using all of the standard inequality measures found in the income inequality literature, and multivariate linear and non-linear regression analyses allowing one to control for observable factors.

Beyond 2026, inclusion of the R-5 scale in future census rounds would make it possible to study changes in financial wellbeing across the Australian population over time and the factors that might be driving such change. In turn, such analyses would enable relevant stakeholders and policymakers to benchmark the effects of their policies and focus on factors that are likely to improve Australians' financial wellbeing in the long run, as well as how financial wellbeing may impact on other areas of Australians' lives.

\section{References}

ABS (2018) Census of Population and Housing: Topic Directions, 2021. https://www.abs.gov.au/ausstats/abs@.nsf/Lookup/2007.0.55.001main+features12021. Accessed on 8 February 2021.

ABS (2020) 2021 Census topics and data release plan. https://www.abs.gov.au/statistics/research/2021census-topics-and-data-release-plan. Accessed on 8 February 2021.

Bonke J and Browning M (2009) The distribution of financial well-being and income within the household. Review of Economics of the Household 7(1): 31-42. https://doi.org/10.1007/s11150-008-9044-3

Botha F, de New J P, and Nicastro N (2020) Developing a short form version of the Commonwealth BankMelbourne Institute reported financial wellbeing scale. Commonwealth Bank of Australia and Melbourne Institute Financial Well-Being Scales Technical Report No 5. Melbourne, University of Melbourne. https://fbe.unimelb.edu.au/ data/assets/pdf file/0003/3403722/CBA-MITechnical-Report-No.-5.pdf.

Botha F, de New J P, de New S C, Ribar DC, and Salamanca N (2021) Implications of COVID-19 labour market shocks for inequality in financial wellbeing. Journal of Population Economics 34(2): 655 689. https://doi.org/10.1007/s00148-020-00821-2

Brown S and Gray D (2016) Household finances and well-being in Australia: An empirical analysis of comparison effects. Journal of Economic Psychology 53: 17-36. https://doi.org/10.1016/i.joep.2015.12.006 
Comerton-Forde C, Ip E, Ribar D C, Ross J, Salamanca N, and Tsiaplias S (2018) Using survey and banking data to measure financial wellbeing. Commonwealth Bank of Australia and Melbourne Institute Financial Well-Being Scales Technical Report No 1. Melbourne, University of Melbourne. https://fbe.unimelb.edu.au/ data/assets/pdf file/0010/2839429/CBA MI Tech Report No 1. pdf.

Comerton-Forde C, de New J P, Salamanca N, Ribar D C, Nicastro A, and Ross J (2020) Measuring financial wellbeing with self-reported and bank-record data. Melbourne Institute Working Paper No. 26/20. Melbourne Institute: Applied Economic \& Social Research, University of Melbourne. https://melbourneinstitute.unimelb.edu.au/publications/workingpapers/search/result?paper=3547050.

Consumer Financial Protection Bureau (CFPB) (2017) CFPB Financial Well-Being Scale. Scale Development Technical Report, Washington DC, CFPB.

Haisken-DeNew J P, Ribar D C, Salamanca N, and Nicastro A (2018) Using survey and banking data to understand Australians' financial wellbeing. Commonwealth Bank of Australia and Melbourne Institute Financial Wellbeing Scales Technical Report No. 2. Melbourne, University of Melbourne. https://fbe.unimelb.edu.au/ data/assets/pdf file/0010/2836324/CBA MI Tech Report No 2. pdf.

Haisken-DeNew J P, Ribar D C, Salamanca N, Nicastro A, and Ross J (2019) Improving the Commonwealth Bank of Australia-Melbourne Institute Observed Financial Wellbeing Scale. Commonwealth Bank of Australia and Melbourne Institute Financial Wellbeing Scales Technical Report No. 3. Melbourne, University of Melbourne. https://fbe.unimelb.edu.au/ data/assets/pdf file/0009/3045708/CBA MI Tech Report No 3. pdf.

Kearns J, Major M, Norman D (2020) How risky is Australian household debt? Reserve Bank of Australia Research Paper RDP 2020-05, Reserve Bank of Australia. https://www.rba.gov.au/publications/rdp/2020/pdf/rdp2020-05.pdf.

Muir K, Hamilton M, Noone J, Marjolin A, Salignac F, and Saunders P (2017) Exploring Financial Wellbeing in the Australian Context. Report for Financial Literacy Australia, Centre for Social Impact \& Social Policy Research Centre, Sydney, University of New South Wales.

Netemeyer R G, Warmath D, Fernandes D, and Lynch J G (2018) How am I doing? Perceived financial wellbeing, its potential antecedents, and its relation to overall well-being. Journal of Consumer Research 45: 68-89. https://doi.org/10.1093/jcr/ucx109 